UDC $339.5 / .9$

DOI: https://doi.org/10.18485/iipe_ria.2021.72.1183.2

Biblid 0543-3657, 72 (2021)

Vol. LXXII, No. 1183, pp. 29-46

Original article

\title{
GEOECONOMIC CONCEPT AND PRACTICE: CLASSIFICATION OF CONTEMPORARY GEOECONOMIC MEANS
}

\author{
Nataša STANOJEVIĆ 1
}

\begin{abstract}
In this research, geoeconomics was analysed separately, as a theoretical concept and as a strategic practice. The aim is to conduct detailed analysis, systematization, classification and explanation of different types of geoeconomic means, as a key part of geoeconomic practice. The basic hypothesis is that in the mass of economic means used by states in international relations, there are natural lines of their demarcation and inner logic, which allow them to be classified and to explain their different purposes. The research has resulted in the classification of geoeconomic means into forced, penetrating and protective means. It provides the basis for a deeper analysis, explanations, and predictions of the geostrategies of participants in international relations. The explanation of the groups of geoeconomic means indicates the expediency of the suggested classification and implies that it can be a useful tool for authors of geoeconomics, but also for planners in creating consistent geoeconomic strategies.
\end{abstract}

Keywords: geoeconomics, geoeconomic means, international relations, political realism.

\section{INTRODUCTION}

"Geoeconomics is still a concept under construction" (Perez, 2021). The term was coined by Edward Luttwak back in 1990, implying a change in international relations (IR) in which the use of economic power takes the place of military and political ones. Geoeconomics, as well as geopolitics, implies the assumptions of political realism about competitiveness and conflict as the basis of international relations. Political realism traditionally involves the assumption of zero-sum

\footnotetext{
${ }^{1}$ Research Fellow, Institute of International Politics and Economics, Belgrade. Email: natasa.stanojevic@diplomacy.bg.ac.rs

The paper presents findings of a study developed as a part of the research project "Serbia and Challenges in International Relations in 2021", financed by the Ministry of Education, Science, and Technological Development of the Republic of Serbia, and conducted by the Institute of International Politics and Economics, Belgrade.
} 
competition from game theory, which implies that the gain of one participant in IR is based on the loss of another.

The concept of geoeconomics did not develop in the period after 1990, due to the new global order and the Washington Consensus supporting the opposite concept of IR: the hope for a more cooperative international system, based on the concept of liberalism in international relations (which need not be related to liberalism within the state) and the mutual benefits of countries and regions, which would eliminate the need for serious conflict, either by military or economic means.

However, in a very short period of time, more precisely with the first challenges the global order faced after the Cold War, a wide and growing gap between these theories and reality manifested itself. Since the beginning of the twentieth century, every economic, social, and, more recently, migrant and health crisis has prompted strong action by nation states, aimed precisely at protecting or promoting national interests while marginalizing supranational institutions and the liberal international order. Reality itself has indicated that competition and conflict are structural parts of IR. Contemporary international relations themselves have created the conditions for a revival of the principle of realism in theories, which involves analysing what $i$, instead of what should be.

The fragility of the liberal concept of international relations, however, is just one of the causes of the geoeconomic revival. Another important factor is the modern, remarkable ascent of China. Contrary to the previously successful strategies of big powers, which based their influence on military power, China achieved its global position using mostly economic means. This country does not exert political pressure, threaten with weapons (except in its territorial disputes), interfere in the internal or international affairs of partner countries, or even use harsh statements in diplomatic relations. Nevertheless, in a very short time, it became one of the most influential world powers. Moreover, China's new geopolitics and geoeconomics is "reshaping old meanings of land and sea power, colored by the economic means of emerging domination" (Šekarić 2020, 371). That gave a strong impetus to renewed interest in geoeconomics as an application of economic means in IR. "China has begun to exert a form of 'geo-economics' influence that is changing the way we think about the nature of international relations in the 21st century" (Beeson 2018, 1).

These circumstances have opened a new chapter in the study of geoeconomics, with a significant increase in the number of authors and organizations researching geoeconomic topics. Given the short period of the geoeconomic revival, "geostrategic aims remain an understudied aspect of contemporary international relations" (Scholvin and Wigel 2019, 1). The number of authors who have analysed this concept is still relatively small, geoeconomic 
means and goals are not classified, and analytical tools to identify and compare geoeconomic strategies are generally lacking.

Geoeconomic means can and should be classified according to many criteria: according to the goal they want to achieve, their purpose, the subjects to which the funds are directed, the nature of the means themselves, and on other grounds. Therefore, the goals of this paper are aimed at supplementing, expanding, and developing the concept of geoeconomics through classifications of modern economic means used by states in their international interactions.

The main hypothesis is that in the mass of economic means used by states in international relations, there are natural lines of their demarcation and inner logic which allow them to be classified, systematized and to explain their different purposes.

In this paper, geoeconomics is seen as an analytical framework, but also as a strategic practice (Scholvin and Wigell 2019). Therefore, geoeconomics as a concept is analysed in the first chapter, while the second chapter deals with geoeconomics as a practice of states, as key subjects of IR. The second chapter is divided into two parts: geoeconomic means and geoeconomic goals. In the first one, the classification of the most often used economic means according to their purpose is proposed. They are classified into forced, penetrating and protective geoeconomic means. The third chapter is a case study of the application of quite different groups of geoeconomic means by the EU and the US in response to the same challenge - China's geoeconomic expansion.

Classifications of geoeconomic means should greatly contribute to the understanding of geoeconomics as a practice. They enable the differentiation of strategic directions of states and the anticipation of the intentions and goals of actors in IR on the basis of applied measures.

\section{GEOECONOMICS AS A THEORETICAL CONCEPT}

As an analytical framework, geoeconomics is strongly based on the theory of political realism in international relations, as a theoretical concept that stresses the competitive and conflictual nature of international relations. According to representatives of realism, the international system is unregulated (the word "anarchic" is often used), since those supranational creations and systemic rules are ineffective. The main subject of IR is nation-states, and their interests are the main driver and motivating force of international relations.

Representatives of political realism consider their concept to be the natural view of international relations, resulting from ordinary and intuitive perception of the way things are. Thus, "political realism requires neither philosophical foundation nor rational justification; it simply articulates the common sense truths of everyday political life" (Spegele 1996). Political realism is, in several forms, dominant in the 
political thought of Thucydides, Machiavelli, and Hobbes, and then in the works of the representatives of classical realism, Hans Morgenthau, Raymond Aron, and George Kennan, an American diplomat who had a key influence on US international politics during the Cold War. The most prominent newer authors are: neo-realist Kenneth Waltz, "defensive" realists Robert Jervis, Stephen Walt and George Quester, as well as "offensive" realist John Mearsheimer.

The disintegration of the Eastern Bloc and the end of the Cold War encouraged the aforementioned theories of democratic peace and international cooperation. After the disappearance of the division of the world into two conflicting polls, the competition between the states had moved from militarystrategic to economic grounds (Babić 2009, 40). The rivalry between the states has not disappeared, but it has been characterized by the application of methods of non-military warfare. The supporters of political realism did not give up competitiveness and conflict as the basic content of international relations.

The antipodes to the concept of realism in international relations are liberalism in IR, as a set of theories separate from the concept of liberalism within states. These theories tend to emphasize cooperation in international relations, diminish the role of nation-states in IR, and advocate the idea that supranational institutions, behaviours, systemic rules and economic connections can overcome the need for conflict, even competitiveness in IR, and soften the violent power of states. Realists do not dispute the nobility of these ideas, but simply deal with international relations in real time, space and circumstances.

However, there are newer authors who advocate the idea that geoeconomics is not opposed to the liberal idealistic concept of cooperation. Among them are Wigell (2016) and Perez (2021), who advocate the thesis that liberal institutionalism can be a part of geoeconomics. According to Wigell, liberal institutionalism can be seen as one type of geostrategies ${ }^{2}$. Perez goes far beyond realism, believing that the mobilization of economic resources, with a geoeconomic focus, could contribute to maintaining the welfare of a state through responsible cooperation rather than sheer competition.

This brief dwelling on the concept of realism in international relations was necessary because its more practical and less theoretical perception of international relations is the core of both concepts: geopolitics and geoeconomics. The theoretical background of geoeconomics is, in fact, the principles of realism in IR applied to the economic means and/or economic goals of states.

\footnotetext{
${ }^{2}$ Although the term "geostrategy" appears in many articles, it has not been defined or explained so far. The term should represent the analysis and synthesis of means and goals both geoeconomic and geopolitical, in various combinations, due to the prefix "geo: refers to both. This would be a significant addition to geoeconomics as a theoretical concept.
} 


\section{Geoeconomics and geopolitics}

Geopolitics is a theoretical concept that explains how states use their political and military power to achieve their political goals, which means the control of a certain aspect of some geographical area (territory, population, natural resources, economic capacity, military resources, etc.). Geoeconomics, on the other hand, is "geostrategic use of economic power" (Wigell 2016).

Most explanations of the concept of geoeconomics are based on bringing it into relation to geopolitics, whether emphasizing similarities or differences. At the same time, the evolution of the concept goes in the direction of separating geoeconomics from geopolitics. With each new work, a certain aspect of this concept is defined, while the common basis remains permanently the state and its interests as the subject of IR.

Luttwak, Huntington and others have analysed the use of geoeconomic power as just another means in the geostrategic toolbox, applied alongside other more traditional geopolitical ones. These authors place geoeconomics closer to geopolitics, emphasizing only changes of strategic means from political to economic, as well as the absence of violence. The transformation of the way conflict was being played out "with disposable capital in the field of firepower, civilian innovation in the field of military-technical advancement, and market penetration in the field of garrisons and bases" (Luttwak 1990, 18). In his later work in 1999, Luttwak added the supremacy of capital over diplomacy. "Capital for investing in industry provided or directed by the state is an equivalent to fire weapons and market penetration, which with the help of the state takes place from military bases and an army on foreign soil as well as diplomatic influence" (Luttwak 1999, 128-129). Huntington stands on the same line, pointing out that "economic power will be increasingly important in determining the primacy or subordination of states" (Huntington 1993).

Although his term "geoeconomics" is the most widely accepted, Luttwak's concept of geoeconomics is not dominant in contemporary geoeconomics. The first group of criticisms is directed at Luttvak's reduction of geoeconomics to the application of a different kind of means. Contemporary authors, such as Wigell and Vihma (2016) and Scholvin and Wigell (2018), suggest a broader understanding of "geoeconomics as a foreign policy strategy and an analytical framework, focused on states as key actors in international relations and foreign policy" (Scholvin and Wigell 2018, p. 15).

Another group of criticisms relates to an overly "linear and consequential change from geopolitics to geoeconomics" (Perez 2021, 161). Namely, Luttwak makes a sharp time distinction between geopolitics and geoeconomics, and he views them as different phases of geostrategy. His simplified understanding of the historical shift from geopolitical to economic means would mean the end not only 
of military interventions, but also of political pressures or alliances, which is clearly not a tendency in international relations. This criticism is joined by Csurgai (2017) and Cowen and Smith (2009). Csurgai (2017) emphasizes that geoeconomics does not substitute geopolitics. Geopolitics and geoeconomics are not diametrically opposed in their historical evolution or in their spatial and geographical application (Cowen and Smith 2009, 24).

Also contrary to Luttwak's basic setting of geoeconomics, there is a small group of authors that includes the application of non-economic, political means in geoeconomics if the goal is clearly geoeconomic. The leading author of this concept is Baru (2012), who extends the concept of geoeconomics by including national power as a means of achieving geoeconomic goals. This extends the concept of geoeconomics to the use of all political non-violent means, such as political pressures, conditioning, interference, etc. According to Baru (2012), geoeconomics can be viewed as "the geopolitical consequences of economic phenomena or as the economic consequences of trends in geopolitics and national power".

Although it seems that in this approach there is no significant difference between geopolitics and geoeconomics, in contemporary, highly layered IR, there are examples in which a clear boundary line cannot really be drawn. When the EU puts political pressure on the countries of the Western Balkans to abolish customs duties or when Germany uses political influence on smaller countries to give up the construction of gas pipelines directly from Russia, but to buy the same gas at higher prices through the EU, are they geopolitical or geoeconomic strategies? It is indisputable that this is a geopolitical strategy, but the economic factor cannot be ignored because it is actually the key driver of the whole strategy.

The prevalence of economic means in international relations is obviously a common element of the concept of geoeconomic. In contrast, the attitude towards geoeconomic goals is the main line of demarcation of different concepts of geoeconomics. There are several different understandings of the goals that states want to achieve using their economic power. These differences in perceptions are also a reflection of the differences in the interpretation of the relation between geopolitics and geoeconomics. The following is an overview of all these varieties of geoeconomic concepts, based on differences in perceptions of geoeconomic goals.

Luttwak, Huntington and other authors put geoeconomics closer to geopolitics, believing that the state's geopolitical goals are the same for geopolitics and geoeconomics, and the difference is only in the means.

Other authors place geoeconomics closer to international economics, distinguishing only clearly economic goals from the stated geoeconomic ones (penetration into foreign markets, access to natural resources, etc.), whereby 
economic means are implied. A group of authors places geoeconomics closer to economics, emphasizing the realisation of strategic economic goals using geoeconomic means. Lorot (2001) defines geoeconomics as "the analysis of economic strategies" which, in addition to economic means, also has economic goals "to protect their own economies or certain well-identified sectors of it, to help their national enterprises acquire technology or to capture certain segments of the world market relative to production or commercialization of a product" (Lorot 2001). The following authors can also be classified here: Cowen and Smith (2009), Csurgai (2017), Kim (2019) and many others. When economic goals are introduced into geoeconomics, the question arises: "What separates geoeconomics from the international economics?" The usual economic goals of countries are economic growth, full employment, positive trade balance, technological progress, security of supply and the like. The geoeconomic approach to the realization of these goals includes specific geopolitical conditions and power relations, political and economic influences of various IR entities, which may or may not be in favour of achieving a specific economic goal of the states. The economy, even the international economy, does not take such fluid and immeasurable factors into account when analysing economic goals.

The third group includes both geoeconomic and political goals in the geoeconomic concept. Blackwill and Harris (2016) put the national interest at the forefront as a goal, thus avoiding limiting it to geopolitical goals. These authors give a comprehensive definition of geoeconomics as "the use of economic means to promote and defend national interests, and to produce beneficial geopolitical results; and the effects of other nations' economic actions on a country's geopolitical goals" (Blackwill and Harris 2016, 20). They further explain that their definition "does not necessarily imply that there are only geopolitical objectives at stake. States design geoeconomic policies that simultaneously advance multiple interests - geopolitical, economic, and otherwise" (Blackwill and Harris 2016, 27). Perez (2021) clearly includes economic and political goals in the geoeconomic concept, not giving preference to either. "Geoeconomics focuses on how states use material foundations ...to achieve goals such as accumulating wealth or pursuing political ends" (Perez 2021, 154).

Although some of these different approaches will encounter a number of disagreements over whether they can be considered geoeconomic or not, this paper does not aim to evaluate these geoeconomic concepts, but takes them all as a valid theoretical basis of geoeconomics. The imposition of a sharp distinction between geoeconomics and geopolitics diminishes the ability to understand the strategies of states in international relations. 


\section{GEOECONOMICS AS A PRACTICE IN INTERNATIONAL RELATIONS}

Geoeconomics, being based on realism, is not a mere theoretical framework, a scientific discipline, but a key area of practical action for nation-states. States have broad geoeconomic, as well as geopolitical strategies, despite the fact that these terms are almost never used in political practice. Each country's geostrategies involve the application of some of a wide range of geoeconomic and geopolitical means, and have more or less clear goals that they want to achieve. According to previous analysis of theoretical approaches, it can be argued that geoeconomics as a practice is the application of economic and political means by countries with the aim to achieve the desired geopolitical and economic goals.

Before explaining and classifying geoeconomic means and goals, it is necessary to emphasize the asymmetry among states as to what means are available to them and what goals they can include in their strategies in general. Shifting the emphasis from military and political methods to economic ones has not diminished the power imbalance at all. Great powers still have "the ability to wield influence at a global level, and act independently even in defiance of the hegemon" (Diesen 2021, 2).

\section{Geoeconomic means}

Although the term of geoeconomics is relatively new, and the theoretical concept is still in its infancy, geoeconomics, as a practice of using economic means in international relations, has existed for centuries. Several examples that are generally known or described in scientific papers and have indisputably the same nature as modern geoeconomic assets are listed below. Probably much older examples can be found, but with controversial comparability with modern geoeconomic means.

The practice of imposing economic sanctions by the state against other states is more than two centuries old (US Embargo of 1807 against France and Britain). The first sanctions imposed by an international organization date back to the founding of the League of Nations in 1919, with the most widely known sanctions against Mussolini's Italy in 1935. The biggest effect of blocking access to natural resources was the oil embargo, introduced in 1973 by OPEC members to the largest Western powers in response to their support for Israel in the Yom Kippur war. The oil embargo led to a 300\% rise in oil prices, which had dramatic consequences for the global economy. The application of different customs duties depending on the country of origin, that is, discrimination in trade policy, has been well-known since the $19^{\text {th }}$ century. For instance, "Canada adapted a double column of tariffs after 1846, Spain in 1877, and Switzerland in the 1880-1890s" (Becuwe and Blancheton 2014). Trade protectionism aimed at preserving the trade balance (not discriminatory towards a 
particular country) was associated with 18th century mercantilism and the works of Adam Smith. The prevalence of dumping prices in international trade was the subject of an article by Jacob Wiener published in 1922 (Wiener 1922).

History abounds in small "wars by other means," as do modern international relations. Geoeconomic means are numerous, diverse and widely known, which greatly facilitates the development and elaboration of geoeconomic as a theoretical concept. Despite that, the lack of their systematization, classification and comparison is emphasized. Although they are a key topic in a growing number of geoeconomic scientific papers, economic means are listed and sorted in only a few papers.

Blackwill and Haris (2016) cite the following, a rather unsystematized list of seven major economic means: "trade policy, investment policy, economic and financial sanctions, cyber, aid, financial and monetary policy, and energy and commodities".

As an economic organization, the World Economic Forum (WEF 2016) offered the most complete list of economic means used in IR. The emphasis is on economic sanctions, but they also listed: trade embargoes, boycotts, tariff discrimination, freezing of capital assets, visa bans, suspension of aid, the prohibition of investment and other capital flows and expropriation, increase in import/export inspections. The term geoeconomics is not mentioned in this WEF report, but the entire report is dedicated to coercive means, which does not make the classification of all geoeconomic means, but comprehensively and logically explains one type, which is currently the largest contribution to the classification of geoeconomic assets.

An attempt to classify all geoeconomic means was made by Troxell (2018), who classified standard economic instruments into two groups: positive and negative. The means are not classified according to the author's own value judgment, but by labeling positive instruments as "carrots" and negative actions as "sticks", he explained the realistic feature of rivalry and competitiveness in IR from the perspective of geoeconomic means. The weakness of the Troxell classification is that economic instruments are not grouped into some logical wholes, but individual instruments are listed. Given the large number of geoeconomic means used in modern IR, they cannot all be listed, and without classifying them into broader groups, the enumerated twenty economic instruments show a high degree of arbitrariness. Also, some of the listed instruments cannot be considered geoeconomic because they are not used by states. For example, among the "positive" instruments there was the contribution of an international financial institution, as well as a private contribution in the field of financial assistance.

Geoeconomic means used in international relations can and should be classified according to many criteria: the goal they want to achieve, their purpose, the subjects to which they are directed, the effects on other players, the nature of 
the means, and others. In this study, the classification of forced, penetrating, and protective economic means based on their purpose was proposed (figure 1).

As shown in Figure 1, depending on the objective, trade restrictions (increase in customs duties, the prohibition or restriction of imports or exports) or protective measures may be forced. If the goal is political, to punish another country or force a political act, then these means are forced by purpose. If the goal is economic, to protect one's own economy, sector, or capital at the expense of other countries, then the same means belong to the group of protective geoeconomic means.

Figure 1. Classification of geoeconomic means
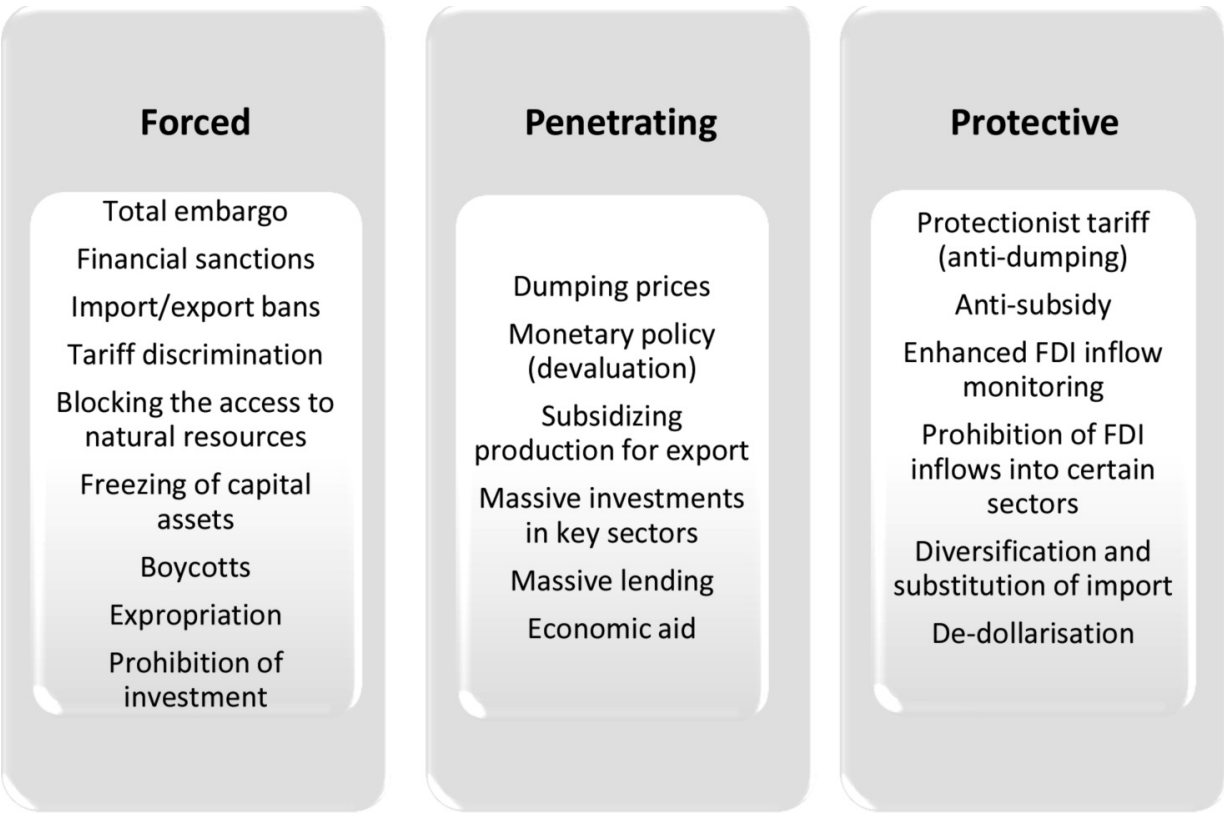

Source: author

Most geoeconomic means are not completely harmless to other participants in international relations. Still, some are obviously more harmful than others. Forced means are most clearly aimed at harming competing countries. In general, forced economic means are not even aimed at the economic prosperity of the country that uses them. In this set of measures, the economic benefits for the subject are secondary, while the primary achievement is geopolitical goals. The typical action of this type, with the application of most of the mentioned measures, was carried out by the US towards Iraq, today towards China and Iran. The abuse of economic power is no longer just a means of the Western powers (although the introduction of economic sanctions is emphasized by the Western tool of coercion) but a global phenomenon. In addition to the usual suspects, the US and the EU, the WEF 
(2016) examined how Brazil, China, India, Iran, Japan, Russia, South Africa, South Korea, and Turkey make use of and respond to economic coercion.

In contrast, penetrating geoeconomic means are strongly oriented to the economic benefits of the IR entity, which is achieved by penetrating the markets of competing countries. Unfavourable effects for competing countries can potentially be huge, but by nature, they are only a possible side effect of using means from this group. China's economic rise is a typical example of the application of all these measures, although not at the same time. The competitive value of China's currency, the yuan (RMB), was one of the most important factors in the successful growth of its economy during the 1990s. Namely, "China's growth was largely based on exports, while exports were based on competitiveness due to the low value of domestic currencies" (Stanojevic 2021, 11-12). The US and the EU have often criticized China for the depressed value of the yuan at an undervalued level but also for dumping prices that have no source in the low value of the currency, but in direct state subsidies. China no longer has a low-value currency and occasionally engages in price dumping, but the modern dominant geoeconomic tool for gaining an advantage over competitors is the incredible expansion of investments abroad within the Belt and Road Initiative (BRI).

The focus of this research is not the effects of geostrategies on partner countries, which has so far been the subject of research in a mass of scientific papers, but only the explanation of different types of geostrategies. However, it must be emphasized here that penetrating measures are not opposed to China's goals of mutual benefit in partnership. Some of the penetrating means, such as dumping prices and the devaluation of the domestic currency, have had detrimental effects on competing economies. These geoeconomic tools have particularly affected the developed countries of Western Europe and the US, whose industry, on which they have risen, has completely lost its primacy in the world economy under the pressure of Chinese competition. On the other hand, modern Chinese penetration into all parts of the world through huge investments has mixed, but more often positive effects on host countries. Since 2013, China has invested hundreds of billions of dollars overseas, mostly in infrastructure and energy projects. It offers investments that are really necessary for the host country, and which cannot be financed from internal financial and other resources. Sometimes, Chinese energy investments are very controversial in terms of environmental standards, while others are controversial in terms of labor relations. In several cases of investing (through loans) in small countries, China has been the target of accusations of imposing "debt slavery". However, in general, all countries in the world, even competing ones, are very interested in Chinese investment, which gives a benign connotation to its penetrating means.

In the group of penetrating means, there is also foreign aid (economic or development in another way). One of the most interesting examples of using 
economic support to achieve geopolitical goals is the work of the United States Agency for International Development (USAID). This important global actor promotes economic and political development in developing states in line with US foreign policy objectives. Economic aid itself is not a goal but a means. The organization is an instrument which pursues American political goals mainly by funding opposition political parties, NGOs, pressure groups, media and all other social entities that it estimates will pursue foreign policy in line with American interests. It is not excluded that these will be the parties in power. In this case, USAID is working to improve the "political atmosphere" (Essex 2013, 51). "Anticommunist allies and movements in Africa and Latin America" were funded through USAID (Essex 2013, 52), as well as "promoting the transition to and consolidation of democratic regimes throughout the world" (USAID 1999), that is, in East and Southeast Europe.

Protective means, as the name itself explains, are naturally aimed at protecting the subject's economy from competitive penetration. While penetrating mechanisms are a strong support for the interactivity of states, i.e., globalization, protective measures are defensive and, if it is a mass phenomenon, they stop the process of globalization and lead to the strengthening of nation-states.

Within this group, the strongest effects have come from trade protectionism measures, which relate to an increase in tariffs, a ban or a reduction in exports or imports. Although the word protective sounds less harmful than penetrating, for the countries targeted by these means, protective measures can have much more detrimental effects. There is no example of a country that implements all measures classified in this group, but there is no country that does not apply at least some of these protective mechanisms. The first of these measures, which relate to trade and investment protectionism, are currently being implemented by the European Union countries. Their protectionism is a response to Chinese geoeconomic expansion, that is, the application of penetrating geoeconomic means and an attempt to preserve part of their previous global influence.

Other measures from this group, diversification and substitution of imports, are generally more economic than geoeconomic means. They gain prefix geo only if they are aimed at protection from very specific import partners, on whom they want to reduce dependence. If it were only economics, the substitution of imports would not make sense, because existing imports are always cheaper than starting new production. So, there are always some geopolitical or geoeconomic reasons for that. This was an important geoeconomic means for the countries of the former Eastern bloc, but today it is very rare and has a significantly different context. These measures do not have as strong defensive nature and purpose as the previous ones. Countries that want to diversify their economies and develop their own production are trying to reduce the degree of import dependence. 
However, since this is a long-term and very slow process, these geoeconomic strategies and means have very little negative impact on import partners.

De-dollarisation is a relatively new geoeconomic tool, reflecting the attempt of large and powerful economies (Russia, China, Turkey) to prevent them from becoming "targets of Western economic coercion" (WEF 2016, 9). They are hedging against dependence on the West (WEF 2016). The one of the interesting examples of de-dollarisation as protective measures are "numerous bilateral agreements on trade in local currencies that China has concluded with Russia, Japan, Iran, Brazil, Australia, Chile, and many African countries" (Stanojević 2020, 30). Another example is the BRICS agreement (Brazil, Russia, India, China, South Africa) from 2012, which stipulates that BRICS member development banks can grant loans in national currencies. Arrangements on mutual loans and borrowings in national currencies were then established more precisely, regardless of whether they were convertible or not (Milenković and Spalović 2013). This geoeconomic tool has clear economic goals: easier and cheaper trade between partner countries, and the harmonization of prices with the markets of these countries, instead of the conditions in the US economy.

On the other hand, the same instrument had a pronounced geopolitical connotation in cases when the leaders of oil-rich countries (Iran, Iraq, Libya and Venezuela) took action or announced that they would sell oil in non-dollar currencies. ${ }^{3}$ Venezuela, under Hugo Chavez, has established barter deals to trade its oil with Latin American countries, and Iran announced back in 1999 that it would accept other convertible currencies besides the dollar. Both countries have been declared by the United States as a global enemy. In 2009, Moammar Gaddafi suggested to the States of the African continent to switch to a new currency, independent of the American dollar: the gold dinar. He was overthrown in 2011 after 42 years of rule. Saddam Hussein converted all its oil transactions under the Oil for Food program to euros in November 2000. He was overthrown in the Iraq war started by the United States in March 2003 after 24 years of rule. Numerous international experts are still writing about the currency background of the overthrow of Saddam Hussein and Muammar Gaddafi. Thus, a completely financial, seemingly politically neutral instrument played a central role in the major reshaping of the global political scene.

\footnotetext{
${ }^{3}$ The introduction of petrodollars (OPEC and other oil exporters oil revenues denominated in U.S. dollars) in the early 1970s represented an exceptional advantage for the American economy. The dominance of the dollar on the world market provides a constant demand for this currency, which significantly prevents inflationary pressures, which would have any other country that would try to issue the currency to that extent.
} 


\section{Geoeconomic goals}

The original idea of the essence of geoeconomics, as it was stated, was the application of economic instead of geopolitical means. This implied that geoeconomics dealt mainly with geopolitical goals, while the economic goals of the states were the area of the international economy. The complexity of the geoeconomic reality after the Cold War division naturally led to the upgrading and expansion of its theoretical concept. Thus, a kind of revival of geoeconomic is marked by a much broader theoretical approach that includes geopolitical means (Baru 2012) and geoeconomic goals (Lorot 2001; Cowen and Smith 2009; Wigell and Vihma 2016; Csurgai 2017; Kim 2019).

The need to look at economic goals in a geopolitical context is the result of the excessive interdependence of states achieved in the last three decades due to the intense process of globalization. The emerging interdependence, begun as a noble attempt at collective progress, very quickly proved to be extremely asymmetric, re-establishing dominance as an important factor in international relations. "Interdependence can manifest itself as dependence of one party on others" (Fjäder 2019). Modern geoeconomic goals are full of terms of political realism, such as: achieving a dominant position in global value chains, market conquest, gaining control over strategic sectors of competitive economies, strengthening influence in an international financial organization that creates rules for international trade for the whole world, increasing the competitive strength of the domestic economy in the world market, or economic power as a goal in itself. These goals can, and often are, formulated in a slightly different way, but this does not change the rivalry in the essence of each of them.

The asymmetry of power has always existed, but not in combination with this degree of interdependence. Prior to globalization, smaller countries were able to achieve many, if not all, of their economic goals without the involvement of a significant number of other international actors. Today, every international economic activity, which goes beyond the regular framework, draws dozens or hundreds of links with other international entities, many of which are in a position to influence the outcome of that activity. Thus, the realization of the economic goals of the state largely depends on whether its geopolitical position is dominated by relations of competition or cooperation.

Although geoeconomics is the scene of the conflicting interests of the actors of IR and still has a solid foundation in political realism, it cannot be disputed that many liberal goals of cooperation and mutual gains are indeed being achieved. The idealistic visions of the common progress of the EU countries have failed many tests (WFC, refugee crisis, the COVID-19 crisis) as stated in the introduction. However, numerous development projects (more often in the field of science, innovation, culture, education, than the economy) within the EU, but 
also independent European countries, are really focused on joint benefits as a geoeconomic goal. However, the symbol of such geoeconomic goals in the 21st century is not the EU, but China. China has already been cited as an example of using purely economic means, and is now emerging as an example of implementing joint benefits goals. China is the global supporter and successful implementer of the so-called win-win strategy, an economic agreement and projects in which all parties win. Although China's geoeconomic means are classified as penetrating, its goals are mutual benefits of partners and realization of long-term interests in a particular country or region. Hundreds of scientific papers and case studies published over the past decade have shown more favorable effects of Chinese investment on host economies than the usual effects of FDI. The rise of China, based on proclaimed and realized win-win goals, has shown that zerosum is not a necessary ingredient of IR, and that some liberal ideals are also an integral part of reality.

\section{CONCLUSIONS}

The research has shown that contemporary international relations, despite the fact that geopolitical means, especially military power, have been significantly replaced by economic ones, are essentially still deeply immersed in political realism, with the prevalence of competition and rivalry. On the other hand, the analysis did not support the assumption of a zero-sum game, according to which it is necessary for one participant to be at a loss in order for another to achieve its goals, and which is often included as a structural segment of political realism.

One of the more important conclusions of this research supports the findings of several recent authors that the geoeconomic concept is not opposed to economic liberalism. As long as common-good goals exist and are realized, the zero-sum cannot be accepted as the rule in international relations. China has shown that economic liberalism and realism are not necessarily opposed. In order to develop further, geoeconomics as a concept requires expansion by recognizing the existence of liberal values in the practice of international relations.

Another extension of geoeconomics that emerges from this research is the inclusion of geopolitical means (other than armed ones) in cases when its goals are to increase or maintain economic power. Examples from modern geoeconomic practice show that some strategies of powerful states cannot be clearly classified as geopolitical or geoeconomic. Therefore, excluding all strategies involving geopolitical means can only result in an unjustifiably reduction in geoeconomics commercial realism.

This research gave a special contribution to the concept of geoeconomics by providing a classification of geoeconomic means into forced, penetrating, and 
protective, made on the basis of their purpose. The classification made it possible to avoid labeling all geoeconomic means and geoeconomics as concepts of the harsh reality of international relations. The given examples of the application of geoeconomic means indicate that forced means are always unwanted by the countries to which they are applied. Protective ones can have negative or neutral effects on other participants since some sorts of penetrating means usually enable mutual benefit.

The proposed classification reflects the internal logic of the choice of means in accordance with the goals and intentions of the state that pursues them. It can be a useful tool for the authors of geoeconomics to have a clearer picture and provide deeper explanation and prediction of the geostrategies of the participants in international relations. Besides, it can make it easier for strategists to create consistent geostrategies.

\section{REFERENCES}

Babić, Blagoje. 2009. "Geoeconomics - Reality and Science". Megatrend revija 6(1): 29-58.

Baru, Sanjaya. 2012. "Geoeconomics and Strategy”. Survival 54(3): 47-58.

Becuwe, Stephane and Bertrand Blancheton. 2014. "The dispersion of customs tariffs in France between 1850 and 1913: Discrimination in trade policy", Research in Economic History, Vol. 30) Emerald Group Publishing Limited, Bingley, pp. 163-183. https://doi.org/10.1108/S0363-3268(2014)0000030004

Beeson, Mark. 2018. "Geoeconomics with Chinese characteristics: the BRI and China's evolving grand strategy". Economic and Political Studies 6(3):240-256.

Blackwill, Robert and Jennifer Haris. 2016. War by Other Means - Geoeconomics and Statecraft. Cambridge, Massachusetts: Harvard university press.

Cowen, Deborah and Neil Smith. 2009. "After Geopolitics? From the Geopolitical Social to the Geoeconomic." Antipode 41: 22-48.

Csurgai, Gyula. 2017. "The Increasing Importance of Geoeconomics in Power Rivalries in the Twenty-First Century". Geopolitics. DOI: http://dx.doi.org/ 10.1080/14650045.2017.1359547

Diesen, Glenn. 2021. Great Power Politics in the Fourth Industrial Revolution: The Geoeconomics of Technological Sovereignty. I.B. Tauris.

Essex, Jamey. 2013. Development, Security, and Aid - geopolitics and geoeconomics at the U.S. agency for international development. Georgia: University of Georgia Press.

Fjäder, Chirstian. 2019. "Interdependence as a dependence: Economic security in the age of global interconnectedness". In: Geoeconomics and power politics in the 21st century: the revival of economic statecraft, edited by Mikael Wigell, Sören Scholvin, and Mika Aaltola, 28-42 Routledge. 
Huntington, Samuel. 1993. "Why international primacy matters". International Security 17(4): 68-83.

Kim, Dong Jung. 2019. "The Perils of Geoeconomics". The Washington Quarterly 42(1): 153-170. DOI: https://doi.org/10.1080/0163660X.2019.1593666

Lorot, Pascal. 2001. "La geoeconomie, nouvelle grammaire des rivalites internationales". L'information géographique, 65(1): 43-52.

Luttwak, Edvard. 1990. "From Geopolitics to GeoEconomics: Logic of Conflict, Grammar of Commerce". The National Interest (20): 17-23.

Luttwak, Edvard. 1999. Turbo capitalism: winners and losers in the global economy. New York: Harper and Collins.

Milenković, Nataša and Katja Spalović. 2013. "Intensification of Russian Chinese cooperation and the transformation of the international monetary system". Економски погледи 15(2) 35-49.

Perez, Ricardo Vega. 2021. "The Development of Geo-economics: A Path Towards an Institutional Liberalism Approach". Austral: Brazilian Journal of Strategy \& International Relations 10(19):154-180.

Scholvin, Soren and Mikael Wigell. 2018. Power politics by economic means: Geoeconomics as an analytical approach and foreign policy practice. Comparative Strategy, 37(1), 73-84

Scholvin, Soren and Mikael Wigell. 2019. "Geoeconomic power politics". In: Geoeconomics and power politics in the 21st century: the revival of economic statecraft, Sören Scholvin, and Mika Aaltola, 1-13. Routledge.

Šekarić, Nevena. 2020. "China's 21st Century Geopolitics and Geoeconomics: An Evidence from the Western Balkans". Medunarodni problemi, 72(2): 356-376. DOI: https://doi.org/10.2298/MEDJP2002356S

Spegele, Roger. 1996. Political realism in international theory. New York: Cambridge University Press.

Stanojević, Nataša. 2020. Effects of China's New Silk Road on the Participating Economies, Eliva Press.

Stanojević, Nataša. 2021. "The rise of European protectionism". In: Europe in changes: the old continent at a new crossroads, edited by Katarina Zakić and Birgül Dimirtaş, 407-424. Institute of International Politics and Economics and Faculty of Security Studies at the University of Belgrade. https://doi.org/ 10.18485/iipe_euchanges.2021.ch20

Troxell, John F. (2018). Geoeconomics, Military review, 98(1): 4-20. Accessed July 31, 2021. https://www.armyupress.army.mil/Portals/7/military-review/ Archives/English/JanFeb-2018-TOC.pdf 
USAID. 1999. US AID Political Party Development Assistance, Centre for Democracy and Governance, U.S. Agency for International Development, Washington, D.C. Accessed July 11, 2021. https://www.usaid.gov/sites/default/ files/documents/2496/200sbd.pdf

Viner, Jacob (1922). "The Prevalence of Dumping in International Trade". Journal of Political Economy, 30(5): 655-680. The University of Chicago Press. July 29, 2021. https://www.jstor.org/stable/pdf/1822739.pdf

Wigell, Mikael and Antto Vihma. 2016. "Geopolitics versus geoeconomics: the case of Russia's geostrategy and its effects on the EU". International Affairs 92(3):605-627. DOI:10.1111/1468-2346.12600

Wigell, Mikael. 2016. "Conceptualizing regional powers' geoeconomic strategies: neo-imperialism, neo-mercantilism, hegemony, and liberal institutionalism. Asia Europe Journal, 14:135-151. DOI 10.1007/s10308-015-0442-x

World Economic Forum. 2016. The Age of Economic Coercion: How Geopolitics is Disrupting Supply Chains, Financial Systems, Energy Markets, Trade and the Internet. World Economic Forum. Accessed July 14, 2021. http://www3.weforum.org/ docs/WEF_Age_of_Economic_coercion.pdf

\section{GEOEKONOMSKI KONCEPT I PRAKSA: KLASIFIKACIJA SAVREMENIH GEOEKONOMSKIH SREDSTAVA}

Apstrakt: U ovom istraživanju geoekonomija je analizirana zasebno kao teorijski koncept i kao praksa država, kao ključnih aktera međunarodnih odnosa. Cilj je da se sprovede detaljnija analiza, sistematizacija, klasifikacija i objašnjenje različitih vrsta geoekonomskih sredstava, kao ključnog dela geoekonomske prakse. Osnovna hipoteza je da u masi ekonomskih sredstava koje dry̌ave koriste u medunarodnim odnosima, postoje prirodne linije njihovog razgraničnja, unutrašnja logika, koja omogúüje da se ona klasifikuju, sistematizuju i objasni njihbova raz̧icita surha. Istraživanje je rezultiralo klasifikacijom geoekonomskih sredstava na prisilna, prodiruća i protektivna. Klasifikacija daje osnovu za jasniju analizu, objašnjenje i predviđanje strategija učesnika u međunarodnim odnosima. Objašnjenje navedenih grupacija geoekonomskih sredstava ukazuje na svrsishodnost predložene klasifikacije i implicira da može biti korisno oruđe za autore geoekonomije, ali i za planere u kreiranju konzistentnih geoekonomskih strategija..

Ključne reči: geoekonomija, geoekonomska sredstva, međunarodni odnosi, politički realizam.

Received: 01.08.2021

Accepted:15.09.2021 